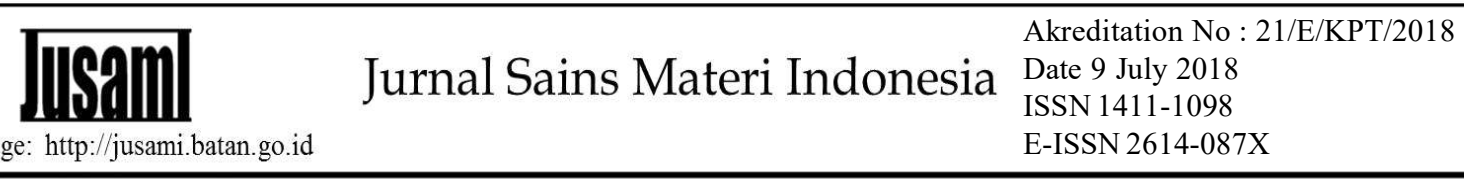

\title{
CALCULATED RADIOACTIVITY YIELDS OF GALLIUM-67 USING MATLAB CODES
}

\author{
I Kambali \\ Center for Accelerator Science and Technology Technology - National Nuclear Energy Agency \\ Jl. Babarsari, Yogyakarta, Indonesia \\ *Email: imamkey@batan.go.id
}

Received: 10 September $2019 \quad$ Revised: 17 October $2019 \quad$ Accepted: 23 October 2019

\begin{abstract}
CALCULATED RADIOACTIVITY YIELDS OF GALLIUM-67 USING MATLAB CODES. In nuclear medicine, gallium-67 $\left({ }^{67} \mathrm{Ga}\right)$ is potentially applied for imaging a certain type of tissue. In this investigation, ${ }^{67} \mathrm{Ga}$ is theoretically studied in terms of its potential radioactivity yields at the end of various energetic proton bombardments. Nuclear cross-sections derived from the Talys Evaluated Nuclear Data Library (TENDL) 2017 were used as the input files, while a Matlab code was developed to perform the yield calculations of ${ }^{67} \mathrm{Zn}(\mathrm{p}, \mathrm{n}){ }^{67} \mathrm{Ga}$ and ${ }^{68} \mathrm{Zn}(\mathrm{p}, 2 \mathrm{n}){ }^{67} \mathrm{Ga}$ nuclear reactions to produce ${ }^{67} \mathrm{Ga}$. Two different targets enriched ${ }^{67} \mathrm{Zn}$ and ${ }^{\text {nat }} \mathrm{Zn}$ targets - were simulated in the calculations. The calculated yields suggested that a maximum of $27.37 \mathrm{MBq} / \mu \mathrm{Ah}$ could be achieved when enriched ${ }^{67} \mathrm{Zn}$ target was irradiated with $15-\mathrm{MeV}$ protons, whereas $46.99 \mathrm{MBq} / \mu \mathrm{Ah}$ could be generated following a $30 \mathrm{MeV}$ proton bombardment of enriched ${ }^{68} \mathrm{Zn}$ target. Various radioactive gallium impurities, i.e. ${ }^{63,64,65,66,68,70} \mathrm{Ga}$ and stable ${ }^{69} \mathrm{Ga}$ isotope were also expected to be generated mostly via (p,n) and (p,2n) reactions when ${ }^{\text {nat }} \mathrm{Zn}$ target was used in the ${ }^{67}$ Ga production. In contrast, radioactive ${ }^{66} \mathrm{Ga}$ and ${ }^{68} \mathrm{Ga}$ impurities were mainly produced following bombardment of enriched ${ }^{67} \mathrm{Zn}$ and ${ }^{68} \mathrm{Zn}$ targets. This study can be used as a reference for future ${ }^{67} \mathrm{Ga}$ radionuclide production.
\end{abstract}

Keywords: Ga-67, Nuclear cross-section, Proton bombardment, Radioactivity yield, TENDL 2017

\begin{abstract}
ABSTRAK
PERHITUNGAN YIELD RADIOAKTIVITAS GALLIUM-67 MENGGUNAKAN MATLAB. Dalam kedokteran nuklir, gallium-67 (67Ga) berpotensi untuk diaplikasikan dalam pencitraan jaringan tertentu yang ada di dalam tubuh. Dalam penelitian ini, $67 \mathrm{Ga}$ dipelajari secara teoritis terutama mengenai potensi yield radioaktivitasnya pada saat akhir iradiasi dengan berkas proton dengan berbaga energi. Tampang lintang reaksi nuklir yag diperoleh dari Talys Evaluated Nuclear Data Library (TENDL) 2017 digunakan sebagai data input, sedangkan software Matlab digunakan untuk menghitung yield reaksi nuklir $67 \mathrm{Zn}(\mathrm{p}, \mathrm{n}) 67 \mathrm{Ga}$ dan $68 \mathrm{Zn}(\mathrm{p}, 2 \mathrm{n}) 67 \mathrm{Ga}$ untuk memproduksi $67 \mathrm{Ga}$. Dua target yang berbeda - 67Zn yang diperkaya and $\mathrm{Zn}$ alam (natZn) - disimulasikan dalam perhitungan tersebut. Hasil perhitungan menunjukkan bahwa proton dengan energi $15 \mathrm{MeV}$ yang ditembakkan ke target diperkaya $67 \mathrm{Zn}$ dapat menghasilkan yield radioaktivitas sebesar $27,37 \mathrm{MBq} / \mu \mathrm{Ajam}$, sedangkan untuk energi proton sebesar $30 \mathrm{MeV}$ dapat dihasilkan yield sebesar 46,99 MBq/ $\mu$ Ajam. Berbagai impuritas radioaktif $\mathrm{Ga}$, antara lain ${ }^{63,64,65,66,68,70} \mathrm{Ga}$ dan impuritas isotop stabil $69 \mathrm{Ga}$ dapat dhasilkan melalui reaksi nuklir (p,n) dan (p,2n) jika Zn alam digunakan di dalam produksi 67Ga. Sebaliknya, impuritas radioaktif 66Ga dan $68 \mathrm{Ga}$ diprediksikan dapat dihasilkan dari iradiasi target diperkaya 67Zn dan 68Zn. Hasil studi ini dapat dijadikan sebagai referensi untuk produksi radionuklida $67 \mathrm{Ga}$ di masa yang akan datang.
\end{abstract}

Kata kunci: Ga-67, Nuclear cross-section, Proton bombardment, Radioactivity yield, TENDL 2017

\section{INTRODUCTION}

Gallium-67 $\left({ }^{67} \mathrm{Ga}\right)$ is a gamma-emitting radioisotope with a half life of 3.3 days suitable as a diagnostic radioisotope for Single Photon Emission
Computed Tomography (SPECT) modality or scintigraphy in nuclear medicine. Recent development suggests that ${ }^{67} \mathrm{Ga}$ is potentially employed to study a 
wide range of diseases, including for detection of Kaposi sarcoma lesions [1], Pulmonary Mycobacterium mucogenicum and Mycobacterium phocaicum Infection [2], osteomyelitis in the diabetic foot [3], Spondylodiscitis imaging [4] and some other diseases [5-10]. When ${ }^{67} \mathrm{Ga}$ is labeled to chemical compound such as citrate, it can be applied for early assessment of psoas muscle abscess [11]. Yet, ${ }^{67} \mathrm{Ga}$ could also be used to monitor therapeutic effectiveness in a patient with relapsing Polychondritis [12]. Furthermore, ${ }^{67} \mathrm{Ga}$ could even be employed as a therapeutic radioisotope as recently reported by Othman and co-workers [13], in which they discovered that ${ }^{67} \mathrm{Ga}$ could be as effective as ${ }^{111}$ In radioisotope for therapy. Previous research suggested various types of chemical complexes which could be labelled with ${ }^{67} \mathrm{Ga}$ [14-16]; thus makes it more flexible to be used in nuclear medicine applications.

While potential use of ${ }^{67} \mathrm{Ga}$ has been well demonstrated elsewhere, its production requirements still need further attention to obtain much better radioactivity yield. Latest experimental cross-sections for ${ }^{68} \mathrm{Zn}\left(\mathrm{p}, 2 \mathrm{n}{ }^{67} \mathrm{Ga}\right.$ nuclear reaction has been published by Pupillo et al [17], which indicates the maximum excitation function around $20 \mathrm{MeV}$ incident protons. The incoming ion beam can be generated using cyclotrons or accelerators which have also been applied for thin layer activation analysis [18] and adsorption studies [19$20]$ as well as ${ }^{18} \mathrm{~F}$ radionuclide production [21-22].

Recent theoretical study using a Monte Carlo code (MCNPX code) [23] predicted that for incident proton energy range between 15 and $26 \mathrm{MeV}$, the expected radioactivity yield was $196.86 \mathrm{MBq} / \mu \mathrm{Ah}$ for ${ }^{68} \mathrm{Zn}(\mathrm{p}, 2 \mathrm{n}){ }^{67} \mathrm{Ga}$ nuclear reaction, whereas lower yield of $88.44 \mathrm{MBq} / \mu \mathrm{Ah}$ was expectedly obtained for ${ }^{67} \mathrm{Zn}(\mathrm{p}, \mathrm{n}){ }^{67} \mathrm{Ga}$ nuclear reaction. Theoretical and experimental data on the end-of-bombardment (EOB) yield of ${ }^{67} \mathrm{Ga}$ have been limited; thus further studies are required.

In this theoretical work, radioactivity yield of two different nuclear reactions relevant for ${ }^{67} \mathrm{Ga}$ production ${ }^{67} \mathrm{Zn}(\mathrm{p}, \mathrm{n}){ }^{67} \mathrm{Ga}$ and ${ }^{68} \mathrm{Zn}(\mathrm{p}, 2 \mathrm{n}){ }^{67} \mathrm{Ga}$ - are calculated using Matlab code, while the corresponding nuclear crosssections are calculated using the TENDL 2017. In addition, various impurities are also predicted in ${ }^{67} \mathrm{Ga}$ production, which have not been reported elsewhere.

\section{MATERIALS AND METHODS}

In this present study, two different targets natural zinc ( $\left.{ }^{\text {nat }} \mathrm{Zn}\right)$ target and enriched zinc targets $\left({ }^{68} \mathrm{Zn}\right.$ and ${ }^{67} \mathrm{Zn}$ targets) - were simulated in the calculations. The range of various energetic protons in the investigated targets were calculated using the Stopping and Range of Ions in Matters (SRIM) 2013 code, while the nuclear cross-sections for ${ }^{67} \mathrm{Zn}(\mathrm{p}, \mathrm{n}){ }^{67} \mathrm{Ga}$ and ${ }^{68} \mathrm{Zn}(\mathrm{p}, 2 \mathrm{n}){ }^{67} \mathrm{Ga}$ and the other relevant nuclear reactions were calculated using the Talys Evaluated Nuclear Data
Library (TENDL) 2017 [24 - 28]. In addition, a Matlab code was developed for calculations of the end-ofbombardment $(\mathrm{EOB})$ yields of the investigated nuclear reactions using the stopping power data derived from the SRIM calculations and the excitation functions obtained from the TENDL 2017. The calculation procedures have been described elsewhere [29-32].

The computer hardware specifications used in these calculations are as follows:

\begin{tabular}{|l|l|}
\hline Device name & LAPTOP-5A5RPLDL \\
\hline Processor & $\begin{array}{l}\text { Intel }{ }^{\circledR C o r e} \text { TM i7-8750H CPU@ } \\
2.20 \mathrm{GHz} 2.21 \mathrm{GHz}\end{array}$ \\
\hline Installed RAM & 8.00 GB \\
\hline Device ID & $\begin{array}{l}\text { 231CFEB0-2A05-4595-894C- } \\
\text { 6D0E8A44E99A }\end{array}$ \\
\hline System type & $\begin{array}{l}\text { 64-bit operating system, x64-based } \\
\text { processor }\end{array}$ \\
\hline
\end{tabular}

In order to study the dependence of proton beam dose on the radioactivity yield, the calculations were simulated for a fixed proton beam current of $50 \mu \mathrm{A}$ while the irradiation time was varied from 12 to 120 minutes, creating proton doses ranging from 10 to $100 \mu \mathrm{Ah}$. For these purposes, several proton energies (9 MeV, $11 \mathrm{MeV}, 18 \mathrm{MeV}, 26 \mathrm{MeV}$ and $30 \mathrm{MeV}$ ) were simulated based on the currently available cyclotrons in Indonesia. In addition, in these calculations, Matlab code was used since it is relatively easy for a simple yield equation, it is a high-performance language for technical computing that integrates computation in an easy-to-use environment where problems and solutions are expressed in familiar mathematical notation.

\section{RESULTS AND DISCUSSION}

\section{TALYS-Evaluated Nuclear Cross-sections}

As mentioned in Section 2, two nuclear reactions are considered in this work, namely ${ }^{67} \mathrm{Zn}(\mathrm{p}, \mathrm{n}){ }^{67} \mathrm{Ga}$ and ${ }^{68} \mathrm{Zn}(\mathrm{p}, 2 \mathrm{n}){ }^{67} \mathrm{Ga}$; thus two enriched targets $\left({ }^{67} \mathrm{Zn}\right.$ and ${ }^{68} \mathrm{Zn}$ targets) are studied. According to the SRIM 2013 calculations, $2.07 \mathrm{~mm}$-thick ${ }^{67} \mathrm{Zn}$ target should be prepared for ${ }^{67} \mathrm{Ga}$ production when the target is bombarded with $30-\mathrm{MeV}$ proton beam. However, a slightly thicker enriched ${ }^{68} \mathrm{Zn}$ target $(2.10 \mathrm{~mm}$ thick $)$ should be used in the ${ }^{67} \mathrm{Ga}$ production for irradiating it with $30-\mathrm{MeV}$ protons.

Based on the TENDL 2017 evaluated excitation function of ${ }^{67} \mathrm{Zn}(\mathrm{p}, \mathrm{n}){ }^{67} \mathrm{Ga}$ reaction the threshold energy is $1.98 \mathrm{MeV}$ with a maximum nuclear cross-section of 563.64 mbarn at proton incident energy of $9 \mathrm{MeV}$ as can be seen in Figure 1. In contrast, higher threshold energy $(12.16 \mathrm{MeV})$ is required for ${ }^{68} \mathrm{Zn}(\mathrm{p}, 2 \mathrm{n}){ }^{67} \mathrm{Ga}$ reaction, though its maximum nuclear cross-section is higher than that of ${ }^{67} \mathrm{Zn}(\mathrm{p}, \mathrm{n}){ }^{67} \mathrm{Ga}$ reaction, which is $675.88 \mathrm{mbarn}$ at proton energy of $18 \mathrm{MeV}$. 


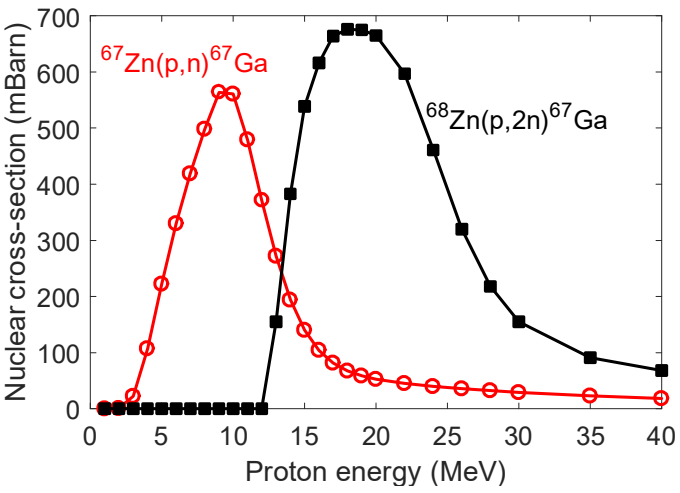

Figure 1. TENDL 2017 nuclear cross-section of ${ }^{67} \mathrm{Zn}(\mathrm{p}, \mathrm{n}){ }^{67} \mathrm{Ga}$ and ${ }^{68} \mathrm{Zn}(\mathrm{p}, 2 \mathrm{n}){ }^{67} \mathrm{Ga}$ nuclear reactions.

\section{EOB Yields of ${ }^{67} \mathrm{Zn}(p, n){ }^{67} \mathrm{Ga}$ and ${ }^{68} \mathrm{Zn}(\mathrm{p}, 2 \mathrm{n}){ }^{67} \mathrm{Ga}$ Nuclear Reactions}

The proton energy dependence of ${ }^{67} \mathrm{Ga}$ radioactivity yield at the EOB for ${ }^{67} \mathrm{Zn}(\mathrm{p}, \mathrm{n}){ }^{67} \mathrm{Ga}$ and ${ }^{68} \mathrm{Zn}(\mathrm{p}, 2 \mathrm{n}){ }^{67} \mathrm{Ga}$ nuclear reactions is shown in Figure 2. In the case of ${ }^{67} \mathrm{Zn}(\mathrm{p}, \mathrm{n}){ }^{67} \mathrm{Ga}$ reaction, as low as $4.09 \mathrm{MBq} /$ $\mu \mathrm{Ah}$ could be produced when enriched ${ }^{67} \mathrm{Zn}$ target is irradiated with $5-\mathrm{MeV}$ protons. The EOB yield increases with increasing proton energy and reaches its maximum yield of $27.37 \mathrm{MBq} / \mu \mathrm{Ah}$ at $15-\mathrm{MeV}$ protons. The yield saturates for proton incident energy of greater than $15 \mathrm{MeV}$.

Again from Figure 2, the EOB yield for ${ }^{68} \mathrm{Zn}(\mathrm{p}, 2 \mathrm{n}){ }^{67} \mathrm{Ga}$ nuclear reaction remains low (as low as $4.18 \mathrm{MBq} / \mu \mathrm{Ah}$ ) when enriched ${ }^{68} \mathrm{Zn}$ target is bombarded with $15-\mathrm{MeV}$ protons. However, the ${ }^{67} \mathrm{Ga}$ radioactivity yield increases dramatically to a maximum value of 46.99 $\mathrm{MBq} / \mu \mathrm{Ah}$ as the proton energy is increased to $30 \mathrm{MeV}$. The EOB yield is expected to level off for proton energy of greater than $30 \mathrm{MeV}$ (not shown in Figure 2).

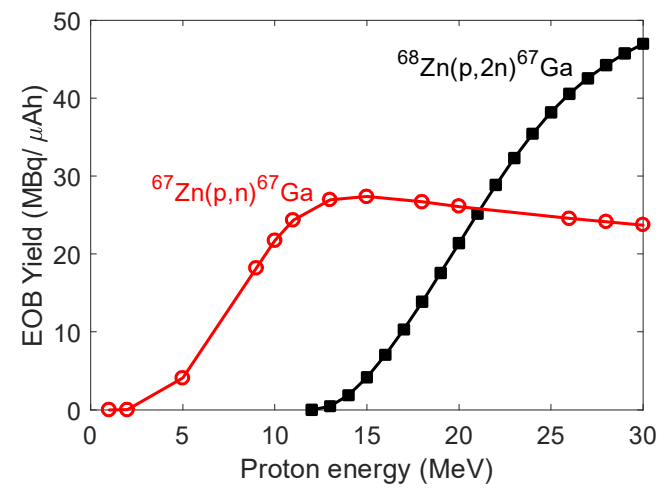

Figure 2. Calculated EOB yields of ${ }^{67} \mathrm{Zn}(\mathrm{p}, \mathrm{n})^{67} \mathrm{Ga}$ and ${ }^{68} \mathrm{Zn}(\mathrm{p}, 2 \mathrm{n}){ }^{67} \mathrm{Ga}$ nuclear reactions.

To achieve a high level of radioactivity yield applicable for scintigraphy in nuclear medicine, one should play around with the proton dose. For ${ }^{67} \mathrm{Zn}(\mathrm{p}, \mathrm{n}){ }^{67} \mathrm{Ga}$ reaction, the expected EOB yields of various proton doses ranging from 10 to $100 \mu \mathrm{Ah}$ for 9 $\mathrm{MeV}, 11 \mathrm{MeV}, 18 \mathrm{MeV}, 26 \mathrm{MeV}$ and $30 \mathrm{MeV}$ protons can

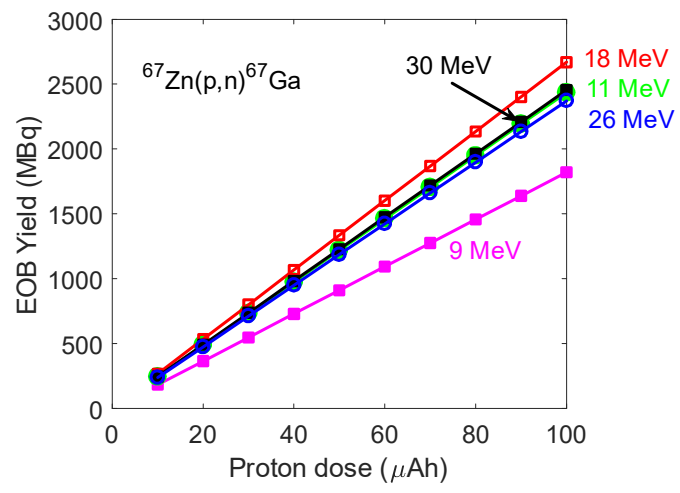

Figure 3. Calculated ${ }^{67} \mathrm{Ga}$ yields at selected proton doses and energies for ${ }^{67} \mathrm{Zn}(\mathrm{p}, \mathrm{n}){ }^{67} \mathrm{Ga}$ nuclear reaction.

be found in Figure 3. When ${ }^{67} \mathrm{Zn}$ target is irradiated with $9 \mathrm{MeV}$-protons at a proton dose of $100 \mu \mathrm{Ah}$, the EOB yield could reach up to $1820.9 \mathrm{MBq}$ which would be sufficient for diagnosing 10 patients. At the same irradiation parameters, for incident protons of $18 \mathrm{MeV}$, the expected EOB yield is $2669 \mathrm{MBq}$, which could be used for diagnosing up to 14 patients. Moreover, there is no significant different in the EOB yield when ${ }^{67} \mathrm{Zn}$ target is bombarded with $11 \mathrm{MeV}, 26 \mathrm{MeV}$ and $30 \mathrm{MeV}$ protons, in which around $2400 \mathrm{MBq}$ is resulted from ${ }^{67} \mathrm{Ga}$ production at $100 \mu \mathrm{Ah}$ proton dose.

For ${ }^{68} \mathrm{Zn}(\mathrm{p}, 2 \mathrm{n}){ }^{67} \mathrm{Ga}$ reaction, the calculated EOB yields of various proton doses ranging from 10 to 100 $\mu \mathrm{Ah}$ for $18 \mathrm{MeV}, 26 \mathrm{MeV}$ and $30 \mathrm{MeV}$ protons are shown in Figure 4. Note that there would be no radioactivity yield resulted from proton bombardment of ${ }^{68} \mathrm{Zn}$ target when the incident proton energy is lower than $12 \mathrm{MeV}$. When $18 \mathrm{MeV}, 26 \mathrm{MeV}$ and $30 \mathrm{MeV}$ protons are bombarded into ${ }^{68} \mathrm{Zn}$ target at $100 \mu \mathrm{Ah}$ proton dose, the expected radioactivity yields are $1387.5 \mathrm{MBq}, 4055.2$ $\mathrm{MBq}$ and $4699 \mathrm{MBq}$ respectively, which would be enough to diagnose 7,21 and 25 patients respectively.

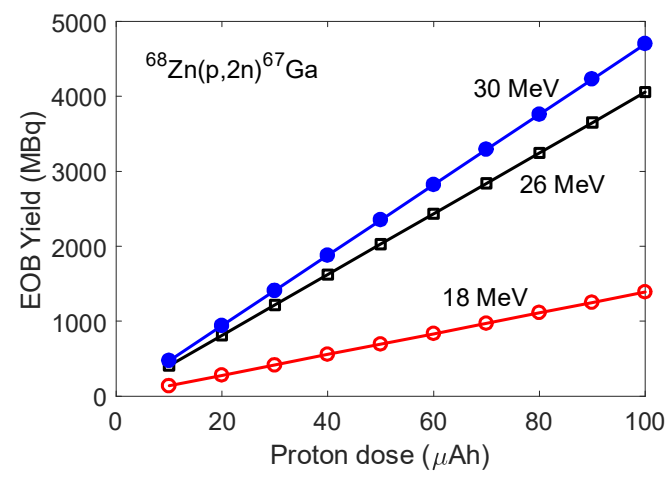

Figure 4. Calculated ${ }^{68} \mathrm{Ge}$ yields at selected proton doses and energies for ${ }^{68} \mathrm{Zn}(\mathrm{p}, 2 \mathrm{n}){ }^{67} \mathrm{Ga}$ nuclear reaction.

\section{Predicted Impurities}

Possible impurities in cyclotron-based radionuclide production can be predicted from their corresponding nuclear reactions and cross-sections. For 
enriched ${ }^{67} \mathrm{Zn}$ target, the expected impurity is ${ }^{66} \mathrm{Ga}$ radionuclide which is due to ${ }^{67} \mathrm{Zn}(\mathrm{p}, 2 \mathrm{n}){ }^{66} \mathrm{Ga}$ nuclear reaction. The ${ }^{66} \mathrm{Ga}$ impurity emits positron with a half life of 9.49 hours. As can be seen in Figure 5, the proton threshold energy for ${ }^{67} \mathrm{Zn}(\mathrm{p}, 2 \mathrm{n}){ }^{66} \mathrm{Ga}$ nuclear reaction is $13.21 \mathrm{MeV}$; thus no ${ }^{66} \mathrm{Ga}$ impurity would be generated at proton energy lower than $13 \mathrm{MeV}$.

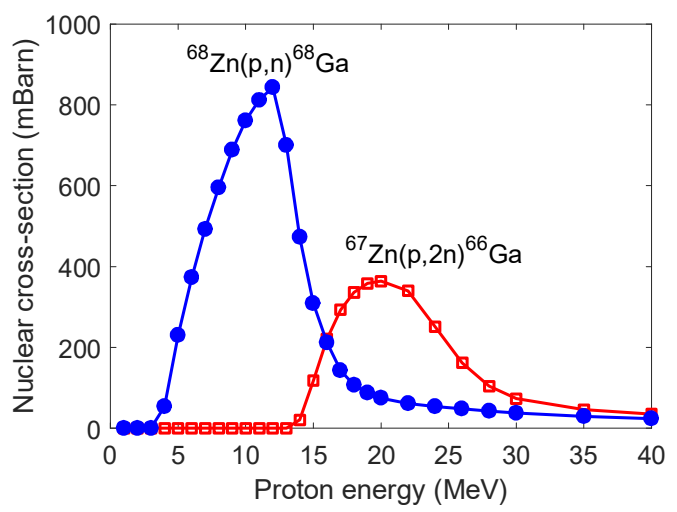

Figure 5. TENDL 2017 excitation functions of ${ }^{67} \mathrm{Zn}(\mathrm{p}, 2 \mathrm{n}){ }^{66} \mathrm{Ga}$ and ${ }^{68} \mathrm{Zn}(\mathrm{p}, \mathrm{n}){ }^{68} \mathrm{Ga}$ nuclear reactions.

For enriched ${ }^{68} \mathrm{Zn}$ target, ${ }^{68} \mathrm{Ga}$ radionuclide is expected to be an impurity as a result of ${ }^{68} \mathrm{Zn}(\mathrm{p}, \mathrm{n})^{68} \mathrm{Ga}$ nuclear reaction. Similar to ${ }^{66} \mathrm{Ga}$ impurity, ${ }^{68} \mathrm{Ga}$ impurity also emits positron, though the half life is much shorter (67.71 minutes). Again, as shown in Figure 5, the proton threshold energy for ${ }^{68} \mathrm{Zn}(\mathrm{p}, \mathrm{n})^{68} \mathrm{Ga}$ nuclear reaction is $3.94 \mathrm{MeV}$; therefore ${ }^{68} \mathrm{Ga}$ impurity would always be generated when producing ${ }^{67} \mathrm{Ga}$ through ${ }^{68} \mathrm{Zn}(\mathrm{p}, 2 \mathrm{n}){ }^{67} \mathrm{Ga}$ nuclear reaction.

When the target of interest is natural zinc $\left({ }^{\text {nat }} \mathrm{Zn}\right)$ containing several $\mathrm{Zn}$ atoms such as ${ }^{64} \mathrm{Zn},{ }^{66} \mathrm{Zn},{ }^{67} \mathrm{Zn}$, ${ }^{68} \mathrm{Zn}$ and ${ }^{70} \mathrm{Zn}$, there would be several nuclear reactions involved in the ${ }^{67} \mathrm{Ga}$ production, which eventually create various impurities. The TENDL 2017 nuclear crosssections for ${ }^{64} \mathrm{Zn},{ }^{66} \mathrm{Zn},{ }^{68} \mathrm{Zn}$ and ${ }^{70} \mathrm{Zn}$ following $(\mathrm{p}, \mathrm{n})$ and $(\mathrm{p}, 2 \mathrm{n})$ nuclear reactions are depicted in Figure 6. The lowest threshold energy $(1.97 \mathrm{MeV})$ is predicted for ${ }^{70} \mathrm{Zn}(\mathrm{p}, \mathrm{n})^{70} \mathrm{Ga}$ reaction while the highest threshold energy $(18.60 \mathrm{MeV})$ is expected for ${ }^{64} \mathrm{Zn}(\mathrm{p}, 2 \mathrm{n}){ }^{63} \mathrm{Ga}$ reaction.

According to the EOB yield calculations, a maximum of $8.7 \mathrm{MBq} / \mu \mathrm{Ah}$ radioactivity yield is produced

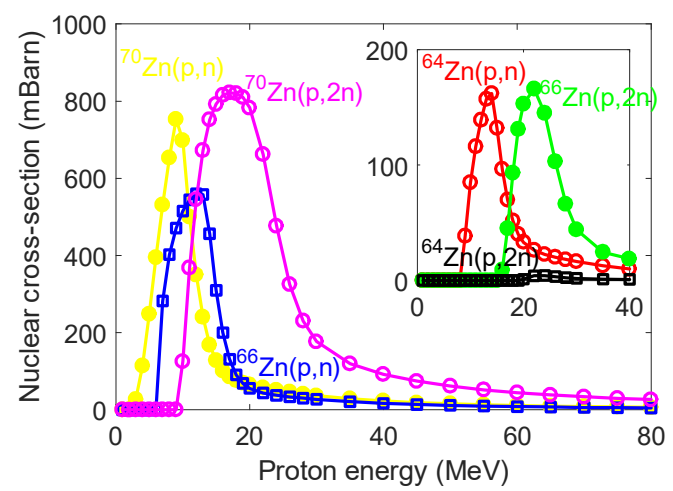

Figure 6. TENDL 2017 excitation functions of protonirradiated natZn target.

when ${ }^{\text {nat }} \mathrm{Zn}$ is irradiated with $15-\mathrm{MeV}$ protons, $18-\mathrm{MeV}$ protons and $30-\mathrm{MeV}$ protons respectively. While the EOB yield is relatively high and sufficient for diagnosing several patients, deep attention should be taken care of particularly dealing with impurities such as ${ }^{63,64,65,66,68,70} \mathrm{Ga}$ and stable isotope ${ }^{69} \mathrm{Ga}$ as listed in Table 1. Most impurities would be positron emitting radionuclides with half lives ranging from as short as 32.4 seconds to 3.26 days as a result of $(\mathrm{p}, \mathrm{n})$ and $(\mathrm{p}, 2 \mathrm{n})$ nuclear reactions.

\section{Comparison with Published Work}

There have been a limited number of publications related to ${ }^{67} \mathrm{Ga}$ production yield, though available experimental work and theoretical calculations can be collected for comparisons. As seen in Table 2, this calculated work closely agrees with semi-experimental data [30-31] as well as the MCNPX calculation [20] with differences ranging from $0.13 \%$ to $13.66 \%$ for proton

Table 2. Comparison of calculated and semi-experimental ${ }^{67} \mathrm{Ga}$ yields from ${ }^{68} \mathrm{Zn}(\mathrm{p}, 2 \mathrm{n}){ }^{67} \mathrm{Ga}$ nuclear reaction.

\begin{tabular}{ccccc}
\hline & \multicolumn{4}{c}{ Radioactivity yield $(\mathrm{MBq} / \mu \mathrm{Ah})$} \\
\cline { 2 - 5 } $\begin{array}{c}\mathrm{E}_{\mathrm{p}} \text { range } \\
(\mathrm{MeV})\end{array}$ & $\begin{array}{c}\text { This } \\
\text { calculated } \\
\text { work }\end{array}$ & $\begin{array}{c}\text { Semi- } \\
\text { experiment } \\
{[33]}\end{array}$ & $\begin{array}{c}\text { MCNPX } \\
\text { calculation } \\
{[23]}\end{array}$ & $\begin{array}{c}\text { Semi- } \\
\text { experiment } \\
{[34]}\end{array}$ \\
\hline $25-14$ & 207.93 & 208.2 & 193.95 & 193.14 \\
$26-15$ & 209.67 & 222 & 196.86 & 204.61 \\
$26-18$ & 153.68 & 178 & 146.86 & 162.8 \\
\hline
\end{tabular}

Table 1. Various impurities predicted during production of $67 \mathrm{Ga}$ radionuclide

\begin{tabular}{|c|c|c|c|c|c|}
\hline $\begin{array}{c}\text { Isotopes of } \\
\mathrm{Zn}\end{array}$ & $\begin{array}{c}\text { Natural } \\
\text { abundance (\%) }\end{array}$ & $\begin{array}{l}\text { Nuclear } \\
\text { reaction }\end{array}$ & $\begin{array}{c}\text { Threshold } \\
\text { energy }(\mathrm{MeV})\end{array}$ & $\begin{array}{l}\text { Decay } \\
\text { mode }\end{array}$ & Half life \\
\hline${ }^{64} \mathrm{Zn}$ & 49.2 & $\begin{array}{c}{ }^{64} \mathrm{Zn}(\mathrm{p}, \mathrm{n}){ }^{64} \mathrm{Ga} \\
{ }^{64} \mathrm{Zn}(\mathrm{p}, 2 \mathrm{n}){ }^{63} \mathrm{Ga}\end{array}$ & $\begin{array}{c}8.12 \\
18.60\end{array}$ & $\begin{array}{l}\text { Positron } \\
\text { positron }\end{array}$ & $\begin{array}{c}2.627 \mathrm{~min} \\
32.4 \mathrm{~s}\end{array}$ \\
\hline${ }^{66} \mathrm{Zn}$ & 27.7 & $\begin{array}{c}{ }^{66} \mathrm{Zn}(\mathrm{p}, \mathrm{n}){ }^{66} \mathrm{Ga} \\
{ }^{66} \mathrm{Zn}(\mathrm{p}, 2 \mathrm{n}){ }^{65} \mathrm{Ga}\end{array}$ & $\begin{array}{c}6.09 \\
15.33\end{array}$ & $\begin{array}{l}\text { Positron } \\
\text { positron }\end{array}$ & $\begin{array}{c}9.49 \mathrm{~h} \\
15.2 \mathrm{~min}\end{array}$ \\
\hline${ }^{67} \mathrm{Zn}$ & 4.0 & $\begin{array}{c}{ }^{67} \mathrm{Zn}(\mathrm{p}, \mathrm{n}){ }^{67} \mathrm{Ga} \\
{ }^{67} \mathrm{Zn}(\mathrm{p}, 2 \mathrm{n})^{66} \mathrm{Ga}\end{array}$ & $\begin{array}{c}1.98 \\
13.21\end{array}$ & $\begin{array}{c}\text { EC } \\
\text { positron }\end{array}$ & $\begin{array}{l}3.26 \mathrm{~d} \\
9.49 \mathrm{~h}\end{array}$ \\
\hline${ }^{68} \mathrm{Zn}$ & 18.5 & $\begin{array}{l}{ }^{68} \mathrm{Zn}(\mathrm{p}, \mathrm{n}){ }^{68} \mathrm{Ga} \\
{ }^{68} \mathrm{Zn}(\mathrm{p}, 2 \mathrm{n})^{67} \mathrm{Ga}\end{array}$ & $\begin{array}{c}3.94 \\
12.16\end{array}$ & $\begin{array}{l}\text { Positron } \\
\text { EC }\end{array}$ & $\begin{array}{c}67.71 \mathrm{~min} \\
3.26 \mathrm{~d}\end{array}$ \\
\hline${ }^{70} \mathrm{Zn}$ & 0.6 & $\begin{array}{c}{ }^{70} \mathrm{Zn}(\mathrm{p}, \mathrm{n})^{70} \mathrm{Ga} \\
{ }^{70} \mathrm{Zn}(\mathrm{p}, 2 \mathrm{n})^{69} \mathrm{Ga}\end{array}$ & $\begin{array}{l}1.97 \\
9.22\end{array}$ & $\begin{array}{l}\text { Beta } \\
\text { stable }\end{array}$ & $\begin{array}{c}21.14 \mathrm{~min} \\
-\end{array}$ \\
\hline
\end{tabular}


energy range between 26 and $14 \mathrm{MeV}$. In the semiexperimental work by Takács et al [30] and Szelecsényi et al [31], thick target yields were calculated from their experimental nuclear cross-sections. Therefore, further experimental investigations are required for better comparisons.

In Indonesia, currently there are three cyclotrons which accelerate protons up to $9 \mathrm{MeV}$ in Gading Pluit Hospital, Jakarta, $11 \mathrm{MeV}$ in Dharmais Cancer Hospital, Jakarta and $18 \mathrm{MeV}$ in Siloam Hospital, Jakarta. Based on the calculated nuclear cross-sections and threshold energies for ${ }^{67} \mathrm{Ga}$ production, the three available cyclotrons can be used to generate ${ }^{67} \mathrm{Ga}$ radionuclide via $\mathrm{Zn}(\mathrm{p}, \mathrm{n}){ }^{67} \mathrm{Ga}$ nuclear reaction. In contrast, only Siloam Hospital's cyclotron is capable of producing ${ }^{67} \mathrm{Ga}$ radionuclide via ${ }^{68} \mathrm{Zn}(\mathrm{p}, 2 \mathrm{n}){ }^{67} \mathrm{Ga}$ nuclear reaction since the threshold energy is $11.98 \mathrm{MeV}$. In addition, predicted impurities also greatly depend on the cyclotron employed in ${ }^{67} \mathrm{Ga}$ production. Using Gading Pluit cyclotron, three radionuclides, such as ${ }^{70} \mathrm{Ga},{ }^{68} \mathrm{Ga}$ and ${ }^{64} \mathrm{Ga}$ may contribute to the presence of impurities, whereas two more isotopes, such as ${ }^{64} \mathrm{Ga}$ and ${ }^{69} \mathrm{Ga}$ could be present in ${ }^{67} \mathrm{Ga}$ production using Dharmais Hospital's cyclotron. Furthermore, all listed isotopes in Table 1 could become impurities when ${ }^{67} \mathrm{Ga}$ is produced using Siloam Hospital's cyclotron.

\section{CONCLUSION}

Production yields of ${ }^{67} \mathrm{Ga}$ radionuclide have been calculated using a developed Matlab code for ${ }^{67} \mathrm{Zn}(\mathrm{p}, \mathrm{n}){ }^{67} \mathrm{Ga}$ and ${ }^{68} \mathrm{Zn}(\mathrm{p}, 2 \mathrm{n}){ }^{67} \mathrm{Ga}$ nuclear reactions. In the EOB yield calculations, the stopping powers were derived from the SRIM-2013 calculations while the nuclear cross-sections were derived using the TENDL 2017. The TENDL 2017 excitation functions indicate that the threshold energy is $1.98 \mathrm{MeV}$ with a maximum nuclear cross-section of 563.64 mbarn at proton incident energy of $9 \mathrm{MeV}$ for ${ }^{67} \mathrm{Zn}(\mathrm{p}, \mathrm{n}){ }^{67} \mathrm{Ga}$ reaction, whereas for ${ }^{68} \mathrm{Zn}(\mathrm{p}, 2 \mathrm{n}){ }^{67} \mathrm{Ga}$ reaction the threshold energy is 12.16 $\mathrm{MeV}$ with maximum nuclear cross-section of 675.88 mbarn at proton energy of $18 \mathrm{MeV}$. The expected maximum EOB yields of ${ }^{67} \mathrm{Zn}(\mathrm{p}, \mathrm{n}){ }^{67} \mathrm{Ga}$ and ${ }^{68} \mathrm{Zn}(\mathrm{p}, 2 \mathrm{n}){ }^{67} \mathrm{Ga}$ reactions are $27.37 \mathrm{MBq} / \mu \mathrm{Ah}$ at $15-\mathrm{MeV}$ protons and $46.99 \mathrm{MBq} /$ $\mu \mathrm{Ah}$ at $30 \mathrm{MeV}$ protons, respectively. Based on the calculated nuclear cross-sections, various impurities could be generated following bombardment of enriched ${ }^{67} \mathrm{Zn}$, enriched ${ }^{68} \mathrm{Zn}$ and ${ }^{\text {nat }} \mathrm{Zn}$ targets. Two impurities $\left({ }^{66} \mathrm{Ga}\right.$ and ${ }^{68} \mathrm{Ga}$ ) are predicted to be produced when protons hit enriched ${ }^{67} \mathrm{Zn}$ and ${ }^{68} \mathrm{Zn}$ targets. On the other hand, ${ }^{63,64,65,66,68,70} \mathrm{Ga}$ and stable ${ }^{69} \mathrm{Ga}$ isotope are expected to be generated mostly via $(p, n)$ and $(p, 2 n)$ reactions when ${ }^{\text {nat }} \mathrm{Zn}$ target is used in the ${ }^{67} \mathrm{Ga}$ production. Comparisons with other theoretical and semi-experimental work indicate that this work is in a good agreement with other published works, though further experimental work is needed for better comparisons. In addition, all available cyclotrons in Indonesia can be used to produce ${ }^{67} \mathrm{Ga}$, though the impurities present during the production depend on the type of cyclotron.

\section{ACKNOWLEDGEMENTS}

The author would like to acknowledge funding from The Indonesian National Nuclear Energy Agency (BATAN) fiscal year 2018. Discussion with researchers and technical staff of the Center for Radioisotope and Radiopharmaceutical Technology, BATAN is also gratefully acknowledged.

\section{REFERENCES}

[1]. J. Suzuki et al., "Usefulness of 18FFluorodeoxyglucose-position emission tomography with computed tomography and gallium-67 scintigraphy for detection of Kaposi sarcoma lesions in a 40-year-old Japanese man with AIDS," IDCases, vol. 2, no. 3, pp. 68-69, 2015.

[2]. S. Hamada, N. Okamoto, and M. Tsukino, "Diffuse Pulmonary Uptake of Gallium-67 Induced by Pulmonary Mycobacterium mucogenicum and Mycobacterium phocaicum Infection," Arch. Bronconeumol. (English Ed., vol. 54, no. 3, pp. 161-163, 2018.

[3]. A. Delcourt et al., "Comparison between Leukoscan ${ }^{\circledR}$ (Sulesomab) and Gallium-67 for the diagnosis of osteomyelitis in the diabetic foot," Diabetes Metab., vol. 31, no. 2, pp. 125-133, 2005.

[4]. M. Raghavan, E. Lazzeri, and C. J. Palestro, "Imaging of Spondylodiscitis," Semin. Nucl. Med., vol. 48, no. 2, pp. 131-147, 2018.

[5]. A. M. J. L. van Kroonenburgh, W. L. van der Meer, R. J. P. Bothof, M. van Tilburg, J. van Tongeren, and A. A. Postma, "Advanced Imaging Techniques in Skull Base Osteomyelitis Due to Malignant Otitis Externa," Curr. Radiol. Rep., vol. 6, no. 3, 2018.

[6]. C. J. Palestro and C. Love, "Role of Nuclear Medicine for Diagnosing Infection of Recently Implanted Lower Extremity Arthroplasties," Semin. Nucl. Med., vol. 47, no. 6, pp. 630-638, 2017.

[7]. J. A. Ioppolo et al., "67Ga-labeled deferoxamine derivatives for imaging bacterial infection: Preparation and screening of functionalized siderophore complexes," Nucl. Med. Biol., vol. 52, pp. 32-41, 2017.

[8]. C. Love and C. J. Palestro, "Nuclear medicine imaging of bone infections," Clin. Radiol., vol. 71, no. 7, pp. 632-646, 2016.

[9]. C. J. Palestro, "Radionuclide imaging of osteomyelitis," in Seminars in Nuclear Medicine, 2015 , pp. 32-46.

[10]. J. Serrano Vicente et al., "67-Gallium SPECT/CT in febrile syndromes of unknown origin," Rev. Esp. Med. Nucl. Imagen Mol., vol. 37, no. 6, pp. $354-358,2018$. 
[11]. R. H. Yang and Y. K. Chu, "Zollinger-Ellison syndrome: Revelation of the gastrinoma triangle," Radiol. Case Reports, vol. 10, no. 1, p. 827, 2015.

[12]. M. C. Chang, S. C. Tsai, and W. Y. Lin, "Dual-phase 99MTc-MIBI parathyroid imaging reveals synchronous parathyroid adenoma and papillary thyroid carcinoma: A case report," Kaohsiung J. Med. Sci., vol. 24, no. 10, pp. 542-547, 2008.

[13]. M. F. bi. Othman, N. R. Mitry, V. J. Lewington, P. J. Blower, and S. Y. A. Terry, "Re-assessing gallium67 as a therapeutic radionuclide," Nucl. Med. Biol., vol. 46, pp. 12-18, 2017.

[14]. Z. Bihari et al., "Synthesis, characterization and biological evaluation of a $67 \mathrm{Ga}$-labeled (ç6-Tyr)Ru(ç5-Cp) peptide complex with the HAV motif," J. Inorg. Biochem., vol. 160, pp. 189-197, 2016.

[15]. E. Koumarianou et al., "Radiolabeling and in vitro evaluation of $67 \mathrm{Ga}-\mathrm{NOTA}$-modular nanotransporter - A potential Auger electron emitting EGFR-targeted radiotherapeutic," Nucl. Med. Biol., vol. 41, no. 6, pp. 441-449, 2014.

[16]. G. Pupillo, T. Sounalet, N. Michel, L. Mou, J. Esposito, and F. Haddad, "New production cross sections for the theranostic radionuclide $67 \mathrm{Cu}$," Nucl. Instruments Methods Phys. Res. Sect. B Beam Interact. with Mater. Atoms, vol. 415, pp. 41-47, 2018.

[17]. I. Kambali and H. Suryanto, "Measurement of seawater flow-induced erosion rates for iron surfaces using thin layer activation technique," $J$. Eng. Technol. Sci., vol. 48, no. 4, pp. 482-494, 2016.

[18]. M. J. Gladys, I. Kambali, M. A. Karolewski, A. Soon, C. Stampfl, and D. J. O'Connor, "Comparison of hydrogen and deuterium adsorption on $\operatorname{Pd}(100)$," J. Chem. Phys., vol. 132, no. 2, 2010.

[19]. I. Kambali, D. J. O'Connor, M. J. Gladys, and M. A. Karolewski, "Determination of deuterium adsorption site on palladium( 100 ) using low energy ion recoil spectroscopy," Appl. Surf. Sci., vol. 254, no. 14, pp. 4245-4250, 2008.

[20]. I. Kambali, H. Suryanto, and Parwanto, "Radioactive by-products of a self-shielded cyclotron and the liquid target system for F-18 routine production," Australas. Phys. Eng. Sci. Med., vol. 39, no. 2, pp. 403-412, 2016.

[21]. I. Kambali et al., "Dependence of 18F Production Yield and Radioactive Impurities on Proton Irradiation Dose," Phys. Res. Int., 2017.
[22]. M. Sadeghi, N. Jokar, T. Kakavand, H. Ghafoori Fard, and C. Tenreiro, "Prediction of $67 \mathrm{Ga}$ production using the Monte Carlo code MCNPX," Appl. Radiat. Isot., vol. 77, pp. 14-17, 2013.

[23]. A. J. Koning and D. Rochman, "Modern Nuclear Data Evaluation with the TALYS Code System," Nucl. Data Sheets, vol. 113, no. 12, pp. 2841-2934, 2012.

[24]. Kambali, "Cyclotron-Based Samarium-153 Production Using Alpha Particle Beam Irradiation," in Journal of Physics: Conference Series, 2018, vol. 1120.

[25]. I. Kambali, "Calculated astatine-211 production yields for radioimmunotherapy," in Journal of Physics: Conference Series, 2018, vol. 1116.

[26]. I. Kambali, "Production of Lu-177 Radionuclide using Deuteron Beams: Comparison between $(\mathrm{d}, \mathrm{n})$ and (d,p) Nuclear Reactions," in Journal of Physics: Conference Series, 2018.

[27]. H. Suryanto and I. Kambali, "A novel method for $57 \mathrm{Ni}$ and $57 \mathrm{Co}$ production using cyclotrongenerated secondary neutrons," Atom Indones., vol. 44, no. 2, pp. 81-87, 2018.

[28]. I. Kambali, "Comprehensive Theoretical Studies on 11-MeV Proton Based Tc-99m Production," Makara J. Sci., vol. 21, no. 3, pp. 125-130, 2017.

[29]. I. Kambali, "Calculated Radioactivity Yields of $\mathrm{Cu}-$ 64 from Proton-Bombarded Ni-64 Targets Using SRIM Codes," Atom Indones., vol. 40, no. 3, pp. 129-134, 2015.

[30]. I. Kambali, "Proton-produced radionuclides for radiodiagnostic modalities in cancer studies," in Journal of Physics: Conference Series, 2019, vol. 1153.

[31]. F. A. Wibowo and I. Kambali, "CalcuYield: A Novel Android-Based Software for Radioactivity Yield Calculations," in Journal of Physics: Conference Series, 2019, vol. 1198, no. 2.

[32]. S. Takács, F. Tárkányi, and A. Hermanne, "Validation and upgrading of the recommended cross-section data of charged particle reactions: Gamma emitter radioisotopes," Nucl. Instruments Methods Phys. Res. Sect. B Beam Interact. with Mater. Atoms, vol. 240, no. 4, pp. 790-802, 2005.

[33]. F. Szelecsényi, T. E. Boothe, S. Takács, F. Tárkányi, and E. Tavano, "Evaluated cross section and thick target yield data bases of $\mathrm{Zn}+\mathrm{p}$ processes for practical applications," Appl. Radiat. Isot., vol. 49, no. 8, pp. 1005-1032, 1998. 